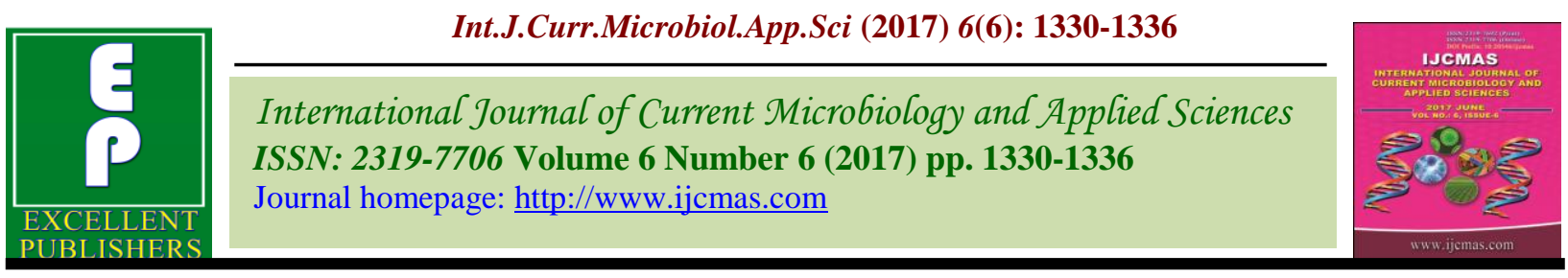

Original Research Article

https://doi.org/10.20546/ijcmas.2017.606.156

\title{
Heterosis Studies for Growth, Earliness, Fruit Yield and Yield Components in Chilli (Capsicum annuum L.)
}

\author{
Mopidevi M. Nagaraju*, I. Sreelathakumary, V.A. Celine, \\ C.R. Sudharmai Devi and P. Manju \\ Department of Olericulture, College of Agriculture, Vellayani 695522, \\ Thiruvananthapuram, Kerala, India \\ *Corresponding author
}

\section{A B S T R A C T}

Keywords

Chilli,

F1 hybrids,

Heterobeltiosis,

Standard

heterosis.

Article Info

Accepted:

19 May 2017

Available Online:

10 June 2017
Heterosis in chilli was studied in 6 x 6 diallel fashion excluding reciprocals. Analysis of variance revealed that, significant difference among the treatments for all the characters studied. Standard heterosis indicated that the hybrids CA 23 x CA 32 (57.90\%) and CA 6 x CA 23 (49.67\%) found to be most promising for green fruit yield and other desirable traits. Based on per se performance and standard heterosis, the hybrids CA $23 \times$ CA 32, CA $8 \times$ CA 32, CA $8 \times$ CA 23 and CA 6 x CA 32 were found superior in respect of seven characters viz., days to first flowering, fruit length, fruit girth, fruit weight, seeds per fruit, green fruit yield and yield per plot. These cross combinations could be exploited in heterosis breeding programme.

\section{Introduction}

Chilli (Capsicum annuum L.) is one of the most important commercially grown spice cum vegetable in the world. The quality in chilli is determined by pungency level, oleoresin, fruit colour, fruit size, pericarp thickness, external glossiness and ascorbic acid content Dhall (2008). Dry matter content of red chilli fruit is an important quality character for the dry powder and dry fruit purpose, which are the major export items of chilli. Even though India ranks first in chilli area and production, the yield potential is low due to poor yielding varieties and high incidence of pests and diseases. From a practical point of view, standard heterosis is the more important of the two levels of heterosis because it is aimed at developing desirable hybrids superior to the existing high yielding commercial varieties. Heterosis breeding is an important genetic tool that can facilitate yield enhancement from 30-400\% and helps to enrich many other desirable quantitative traits in crops Srivastava (2000).

One of the methods to achieve quantum jump in yield and quality is heterosis breeding. Therefore, to meet this objective in a shorter time the heterosis breeding has been 
undertaken to develop and identify the suitable best performing hybrids.

\section{Materials and Methods}

Six genetically diverse parental lines viz., CA $3\left(\mathrm{P}_{1}\right), \mathrm{CA} 5\left(\mathrm{P}_{2}\right), \mathrm{CA} 6\left(\mathrm{P}_{3}\right), \mathrm{CA} 8\left(\mathrm{P}_{4}\right), \mathrm{CA}$ $23\left(\mathrm{P}_{5}\right)$ and CA $32\left(\mathrm{P}_{6}\right)$ were crossed in diallel mating design excluding reciprocal to get 15 cross combinations. All the 15 hybrids along with their parents were raised in a randomized block design with three replications during 2014-15. The experiment was conducted at College of Agriculture, Vellayani, Kerela Agricultural University, Thiruvananthapurum. The plot size for each treatment was $3.6 \mathrm{~m} \mathrm{x}$ $1.8 \mathrm{~m}$ where in both row-to-row and plant-toplant spacing was $45 \times 45 \mathrm{~cm}$. The crop was raised as per the standard package of practice. Timely management practices were followed to grow a good crop. Five plants were randomly selected per plot for recording data on plant height $(\mathrm{cm})$, primary branches per plant, days to first flowering, fruits per plant, fruit length $(\mathrm{cm})$, fruit girth $(\mathrm{cm})$, fruit weight $(\mathrm{g})$, seeds per fruit, green fruit yield per plant (g) and yield per plot $(\mathrm{kg})$. The magnitude of heterosis as the difference in $\mathrm{F}_{1}$ performance over mid parent (MP), better parent (BP) and standard check (Arka Harita) in percentage was calculated for these characters. Estimation of heterosis was carried out following the methods suggested by Turner (1953) and Hayes et al., (1995).

\section{Results and Discussion}

\section{Analysis of variance for the experimental design}

Analysis of variance revealed that, significant difference among the treatment for all the traits studied. Variance due to parents was significant for all characters except days to first flowering and. The parents vs. hybrids showed significant differences for all the characters for this study (Table 1). This indicated that materials used for present investigation had adequate diversity for different characters. Heterosis breeding is a potential method to achieve improvement in production and productivity of chilli that otherwise cannot be achieved through existing traditional methods. The positive effects of heterosis were considered desirable for all the characters except days to first flowering and days to first harvest. A wide range of heterosis over mid parent $(\mathrm{RH})$, better parent (HB) and standard check ( $\mathrm{SH})$ was observed in $F_{1}$ generation for most of the characters studied and presented in table 2 .

Heterosis observed for most of the characters was high and in varying proportion due to dominance gene effects rather than additive genes and it was high especially in crosses involving diverse parents which suggested that diversity based on plant type can be effectively used for exploitation of heterosis. Further, there was close agreement between per se performance and heterosis as the crosses which showed high mean performance also possessed greater heterosis percentage both over better parent as well as standard check.

Mean performance of parents and $F_{1}$ hybrids in relation to their heterobeltiosis and heterosis

\section{Plant height $(\mathrm{cm})$}

Plant height is an important growth parameter from productivity and crop management point of view. The magnitudes of heterosis for plant height were ranged from -22.04 to $18.99 \%$ and -48.87 to $-12.81 \%$ over better parent and standard check, respectively. The highest positive heterobeltiosis was recorded in cross combinations namely, CA 6 x CA 23 (18.99\%), CA 6 x CA 8 (16.76\%) and CA $8 \times$ CA $23(13.82 \%)$ for plant height (Table 3). Fifteen $F_{1}$ crosses exhibited significant negative heterosis over standard check for plant height. 


\section{Primary branches per plant}

The primary branches per plant of parents mean value varied from 3.2 to 4.1 (Table 2). The magnitudes of heterosis for plant height were ranged from -34.69 to $30.19 \%$ and 56.16 to $-5.48 \%$ over better parent and standard check, respectively. The cross combination CA 6 x CA 32 (30.19\%) followed CA 3 x CA 5 (22.22\%) had exhibited significant positive heterobeltiosis. None of the crosses were found with significant positive heterosis over standard check.

\section{Days to first flowering}

Early flowering is generally an indication of early yield. The magnitudes of heterosis for days to first flowering were ranged from 20.78 to $12.33 \%$ and -26.95 to $3.58 \%$ over better parent and standard check, respectively. Ten $F_{1}$ crosses were found with significant negative heterosis over better parent. The top three hybrids for days to first flowering over standard check were CA 23 x CA 32 ($26.95 \%)$, CA $5 \times$ CA $32(-26.74 \%)$ and CA 6 $x$ CA $8(-24.42 \%)$ (Table 3). These results are in agreement with those of Gandhi et al., (2000) and Shankarnag et al., (2006) who also got heterotic crosses of high frequency over better parent and standard check for days to first flowering, days to first harvest, growth and yield traits.

\section{Fruits per plant}

In chilli, number of fruits per plant is the most important primary component of total yield. The number of fruits produced by parental lines and F1hybrids mean value varied from 39.33 to 109 and 20.66 to 147.33 respectively (Table 2). Among the parents, the maximum fruits per plant was observed in CA 8 (109) fallowed by CA 5 (91) and CA 3 (88.66). The magnitudes of heterosis for fruits per plant were ranged from -76.69 to $71.97 \%$ and 88.89 to $-20.79 \%$ over better parent and standard check, respectively. Eight $\mathrm{F}_{1}$ hybrids were found significant positive heterosis for fruits per plant over better parent. The cross combination CA 6 x CA 23 (71.97\%) followed by CA 6 x CA 32 (43.93\%) and CA 6 x CA 8 (35.17\%) had exhibited highly significant positive heterobeltiosis. None of the crosses were found with significant positive heterosis over standard check.

\section{Fruit length (cm)}

Among the parents, the maximum fruit length was observed in CA 3 (15.21) fallowed by CA 32 (13.33) and CA 8 (11.41). The magnitudes of heterosis for fruit length were ranged from -15.38 to $22.31 \%$ and 29.09 to $70.40 \%$ over better parent and standard check, respectively. Only two crosses were found with positive significant heterosis for fruit length in $F_{1}$ generation over better parent and fifteen crosses were found with significant positive heterosis over standard check. The top ranking hybrids for fruit length over standard check were CA 3 x CA $32(70.40 \%)$, CA $8 \times$ CA $32(64.74 \%)$ and CA $3 \times$ CA 5 $(60.19 \%)$.

\section{Fruit girth (cm)}

The primary branches per plant of parents mean value varied from 4.53 to 9.28 (Table 2 ). The magnitudes of heterosis for fruit girth were ranged from -42.56 to -1.08 and 12.88 to $108.71 \%$ over better parent and standard check, respectively. None of the hybrids showed positive heterobetiosis for fruit girth while fourteen crosses were found with significant positive standard heterosis. The cross combination CA 3 x CA $23(108.71 \%)$ followed by CA 23 x CA $32(107.84 \%)$ and CA 8 x CA $23(92.16 \%)$ had exhibited the highest significant positive heterosis over standard check. 
Table.1 Analysis of variance for 10 characters in chilli

\begin{tabular}{|c|c|c|c|c|c|c|c|c|c|c|c|}
\hline $\begin{array}{l}\text { Source of } \\
\text { variation }\end{array}$ & d.f & $\begin{array}{l}\text { Plant } \\
\text { height } \\
(\mathrm{cm})\end{array}$ & $\begin{array}{c}\text { Primary } \\
\text { branche } \\
\text { s per } \\
\text { plant }\end{array}$ & $\begin{array}{l}\text { Days to } \\
\text { first } \\
\text { floweri } \\
\text { ng }\end{array}$ & $\begin{array}{l}\text { Fruits } \\
\text { per } \\
\text { plant }\end{array}$ & $\begin{array}{l}\text { Fruit } \\
\text { length } \\
(\mathrm{cm})\end{array}$ & $\begin{array}{l}\text { Fruit } \\
\text { girth } \\
(\mathrm{cm})\end{array}$ & $\begin{array}{c}\text { Fruit } \\
\text { weight } \\
(\mathrm{g})\end{array}$ & $\begin{array}{l}\text { Seeds } \\
\text { per fruit }\end{array}$ & $\begin{array}{l}\text { Green } \\
\text { fruit } \\
\text { yield } \\
\text { per } \\
\text { plant } \\
\text { (g) }\end{array}$ & $\begin{array}{l}\text { Yield } \\
\text { per plot } \\
(\mathrm{kg})\end{array}$ \\
\hline Replication & 2 & 10.39 & 0.23 & 5.79 & 74.58 & 1.58 & 0.10 & 0.069 & 218.11 & 850.40 & 10.213 \\
\hline Treatments & 20 & $\begin{array}{c}114.45 \\
* *\end{array}$ & $0.82 * *$ & $\begin{array}{c}19.28 \\
* *\end{array}$ & $\begin{array}{c}2775.72 \\
* *\end{array}$ & $10.42 * *$ & $4.69 * *$ & $\begin{array}{c}12.68 \\
* *\end{array}$ & $\begin{array}{c}579.78 \\
* *\end{array}$ & $\begin{array}{c}149841 . \\
70 * *\end{array}$ & $\begin{array}{c}124.92 \\
* *\end{array}$ \\
\hline Parents & 5 & $\begin{array}{c}113.93 \\
* *\end{array}$ & 0.32 & 3.17 & $\begin{array}{c}1612.66 \\
* *\end{array}$ & $26.78 * *$ & $9.86 * *$ & $\begin{array}{c}12.82 \\
* *\end{array}$ & $\begin{array}{c}573.03 \\
* \\
\end{array}$ & $\begin{array}{c}31181.2 \\
5 * *\end{array}$ & $\begin{array}{c}40.89 \\
* *\end{array}$ \\
\hline Hybrids & 14 & $\begin{array}{c}103.75 \\
* *\end{array}$ & $0.97 * *$ & $\begin{array}{c}19.96 \\
* * \\
\end{array}$ & $\begin{array}{c}2615.83 \\
* *\end{array}$ & $3.65 * *$ & $3.10 * *$ & $\begin{array}{c}13.24 \\
* * \\
\end{array}$ & $\begin{array}{c}472.87 \\
* \\
\end{array}$ & $\begin{array}{c}133129 . \\
40 * *\end{array}$ & $\begin{array}{c}91.95 \\
* *\end{array}$ \\
\hline $\begin{array}{c}\text { Parents Vs. } \\
\text { Hybrids }\end{array}$ & 1 & $\begin{array}{c}266.90 \\
* *\end{array}$ & $1.19 * *$ & $\begin{array}{c}90.40 \\
* *\end{array}$ & $\begin{array}{c}10829.4 \\
3 * * \\
\end{array}$ & $23.39 * *$ & $1.21 * *$ & $4.02 *$ & $\begin{array}{c}2110.17 \\
* *\end{array}$ & $\begin{array}{c}977116 . \\
30 * *\end{array}$ & $\begin{array}{c}1006.72 \\
* *\end{array}$ \\
\hline Error & 40 & 9.42 & 0.16 & 1.89 & 52.07 & 0.96 & 0.10 & 0.90 & 199.61 & 1438.86 & 3.63 \\
\hline
\end{tabular}

*Significant at 5 per cent level ** Significant at 1 per cent level

Table. 2 Per se performance of parents, hybrids and heterosis range of 10 characters in chilli

\begin{tabular}{|c|c|c|c|c|c|c|}
\hline \multirow[t]{3}{*}{ Characters } & \multicolumn{5}{|c|}{ Range } & \multirow{3}{*}{$\begin{array}{l}\text { Best parents (Based on per } \\
\text { se performance) }\end{array}$} \\
\hline & \multicolumn{2}{|c|}{ Per se performance } & \multicolumn{3}{|c|}{ Heterosis $(\%)$} & \\
\hline & Parents & Crosses & MP & $\mathrm{BP}$ & $\mathrm{SC}$ & \\
\hline $\begin{array}{l}\text { Plant height } \\
\text { (cm) }\end{array}$ & $\begin{array}{l}42.57 \text { to } \\
60.74\end{array}$ & $\begin{array}{c}36.97 \text { to } \\
63.04\end{array}$ & $\begin{array}{c}-17.84 \text { to } \\
28.72\end{array}$ & $\begin{array}{c}-22.04 \text { to } \\
18.99\end{array}$ & $\begin{array}{l}-48.87 \text { to }- \\
12.81\end{array}$ & $\begin{array}{l}\text { CA } 32 \text { (60.74), CA } 5 \\
(50.26), \text { CA } 6(50.15)\end{array}$ \\
\hline $\begin{array}{l}\text { Primary } \\
\text { branches per } \\
\text { plant }\end{array}$ & 3.2 to 4.1 & 2.1 to 4.6 & $\begin{array}{c}-34.02 \text { to } \\
30.19\end{array}$ & $\begin{array}{c}-34.69 \text { to } \\
30.19\end{array}$ & $\begin{array}{l}-56.16 \text { to }- \\
5.48\end{array}$ & $\begin{array}{c}\text { CA } 8 \text { (4.1), CA } 5(3.6), \\
\text { CA } 32(3.5)\end{array}$ \\
\hline $\begin{array}{l}\text { Days to first } \\
\text { flowering }\end{array}$ & $\begin{array}{l}26.86 \text { to } \\
29.73 \\
\end{array}$ & $\begin{array}{c}23.13 \text { to } \\
32.80\end{array}$ & $\begin{array}{c}-20.69 \text { to } \\
17.00\end{array}$ & $\begin{array}{c}-20.78 \text { to } \\
12.33\end{array}$ & $\begin{array}{c}-26.95 \text { to } \\
3.58\end{array}$ & $\begin{array}{l}\text { CA } 3 \text { (26.86), CA } 8 \\
(28.35), \text { CA } 32(29.13)\end{array}$ \\
\hline Fruits per plant & $\begin{array}{c}39.33 \text { to } \\
109\end{array}$ & $\begin{array}{c}20.66 \text { to } \\
147.33\end{array}$ & $\begin{array}{l}-67.71 \text { to } \\
70.54\end{array}$ & $\begin{array}{l}-76.69 \text { to } \\
71.97\end{array}$ & $\begin{array}{l}-88.89 \text { to }- \\
20.79\end{array}$ & $\begin{array}{l}\text { CA } 8 \text { (109.00), CA } 5 \\
(91.00), \text { CA } 3(88.66)\end{array}$ \\
\hline Fruit length $(\mathrm{cm})$ & $\begin{array}{c}6.30 \text { to } \\
15.21\end{array}$ & $\begin{array}{l}10.96 \text { to } \\
14.46\end{array}$ & $\begin{array}{l}-3.33 \text { to } \\
54.83\end{array}$ & $\begin{array}{c}-15.38 \text { to } \\
22.31\end{array}$ & $\begin{array}{c}29.09 \text { to } \\
70.40\end{array}$ & $\begin{array}{l}\text { CA } 3 \text { (15.21), CA } 32 \\
(13.33), \text { CA } 8(11.41)\end{array}$ \\
\hline Fruit girth $(\mathrm{cm})$ & 4.53 to 9.28 & 3.88 to 7.18 & $\begin{array}{c}-23.98 \text { to } \\
4.57 \\
\end{array}$ & $\begin{array}{l}-42.56 \text { to }- \\
1.08\end{array}$ & $\begin{array}{c}12.88 \text { to } \\
108.71 \\
\end{array}$ & $\begin{array}{l}\text { CA } 23(9.28) \text {, CA } 3 \text { (5.36), } \\
\text { CA } 32(5.35)\end{array}$ \\
\hline Fruit weight $(\mathrm{g})$ & $\begin{array}{c}6.76 \text { to } \\
11.21\end{array}$ & $\begin{array}{c}6.34 \text { to } \\
14.43\end{array}$ & $\begin{array}{c}-28.57 \text { to } \\
29.53\end{array}$ & $\begin{array}{c}-42.30 \text { to } \\
28.75\end{array}$ & $\begin{array}{l}78.87 \text { to } \\
309.36\end{array}$ & $\begin{array}{l}\text { CA } 23 \text { (11.21), CA } 32 \\
(11.07), \text { CA } 3 \text { (10.99) }\end{array}$ \\
\hline Seeds per fruit & $\begin{array}{l}83.66 \text { to } \\
120.00\end{array}$ & $\begin{array}{l}99.66 \text { to } \\
147.33\end{array}$ & $\begin{array}{l}-2.43 \text { to } \\
43.04\end{array}$ & $\begin{array}{c}-14.90 \text { to } \\
43.04\end{array}$ & $\begin{array}{c}42.11 \text { to } \\
111.48\end{array}$ & $\begin{array}{l}\text { CA } 6 \text { (124.00), CA } 23 \\
(116.33), \text { CA } 5(109.00)\end{array}$ \\
\hline $\begin{array}{l}\text { Green fruit yield } \\
\text { per plant }(\mathrm{g})\end{array}$ & $\begin{array}{l}311.20 \text { to } \\
590.02\end{array}$ & $\begin{array}{l}177.66 \text { to } \\
1048.21\end{array}$ & $\begin{array}{l}14.90 \text { to } \\
162.68\end{array}$ & $\begin{array}{l}-69.06 \text { to } \\
123.13\end{array}$ & $\begin{array}{c}-73.24 \text { to } \\
57.90\end{array}$ & $\begin{array}{l}\text { CA } 32(590.02), \text { CA } 3 \\
(574.26), \text { CA } 8 \text { (520.07) }\end{array}$ \\
\hline $\begin{array}{l}\text { Yield per plot } \\
(\mathrm{kg})\end{array}$ & $\begin{array}{c}6.07 \text { to } \\
16.30\end{array}$ & $\begin{array}{c}3.04 \text { to } \\
26.34\end{array}$ & $\begin{array}{c}-70.08 \text { to } \\
227.18\end{array}$ & $\begin{array}{c}-78.68 \text { to } \\
174.48\end{array}$ & $\begin{array}{l}-80.86 \text { to } \\
65.53\end{array}$ & $\begin{array}{l}\text { CA } 32 \text { (16.30), CA } 3 \\
(14.29), \text { CA } 8(10.96)\end{array}$ \\
\hline
\end{tabular}


Table.3 Top three hybrids over mid parent, better parent and standard check for 10 characters and number of significant hybrids in desirable direction in chilli

\begin{tabular}{|c|c|c|c|c|c|c|}
\hline \multirow[t]{2}{*}{ Characters } & \multicolumn{3}{|c|}{ Top hybrids based on heterosis over } & \multicolumn{3}{|c|}{$\begin{array}{c}\text { No of hybrids in desirable } \\
\text { direction }\end{array}$} \\
\hline & MP & BP & $\mathrm{SC}$ & $\mathrm{RH}$ & $\mathrm{HB}$ & $\mathrm{SH}$ \\
\hline Plant height $(\mathrm{cm})$ & $\begin{array}{c}\text { CA } 6 \text { x CA } 23(28.72) \\
\text { CA } 23 \text { x CA } 32 \\
(22.04), \text { CA } 6 \text { x CA } 8 \\
(21.40)\end{array}$ & $\begin{array}{c}\text { CA } 6 \text { x CA } 23 \\
(18.99), \text { CA } 6 \text { x CA } \\
8(16.76), \text { CA } 8 \times x \\
\text { CA } 23(13.82)\end{array}$ & $\begin{array}{c}\text { CA } 23 \text { x CA } 32(- \\
12.81), \text { CA } 6 \text { x CA } \\
23(-17.47), \text { CA } 5 \text { x } \\
\text { CA } 32(-18.17)\end{array}$ & 8 & 3 & 15 \\
\hline $\begin{array}{l}\text { Primary branches per } \\
\text { plant }\end{array}$ & $\begin{array}{l}\text { CA } 6 \text { x CA } 32(30.19), \\
\text { CA } 3 \text { x CA } 5(29.41), \\
\text { CA } 6 \text { x CA } 23(23.53)\end{array}$ & $\begin{array}{l}\text { CA } 6 \text { x CA } 32 \\
(30.19), \text { CA } 3 \times \text { CA } \\
5(22.22) \\
\end{array}$ & -- & 4 & 2 & 0 \\
\hline $\begin{array}{l}\text { Days to first } \\
\text { flowering }\end{array}$ & $\begin{array}{c}\text { CA } 23 \text { x CA } 32(- \\
20.69), \text { CA } 5 \text { x CA } 32 \\
(-20.55), \text { CA } 6 \text { x CA } 8 \\
(-17.59)\end{array}$ & $\begin{array}{c}\text { CA } 23 \text { x CA } 32(- \\
20.78), \text { CA } 5 \text { x CA } \\
32(-20.73), \text { CA } 6 \text { x } \\
\text { CA } 8(-19.51)\end{array}$ & $\begin{array}{c}\text { CA } 23 \text { x CA } 32(- \\
26.95), \text { CA } 5 \text { x CA } \\
32(-26.74), \text { CA } 6 \text { x } \\
\text { CA } 8(-24.42)\end{array}$ & 9 & 10 & 14 \\
\hline Fruits per plant & $\begin{array}{c}\text { CA } 6 \text { x CA } 23 \\
(130.25), \text { CA } 8 \times \text { CA } \\
23(73.48), \text { CA } 23 \text { x } \\
\text { CA } 32(70.54)\end{array}$ & $\begin{array}{c}\text { CA } 6 \text { x CA } 23 \\
(71.97), \text { CA } 6 \text { x CA } \\
32(43.93), \text { CA } 6 \text { x } \\
\text { CA } 8(35.17)\end{array}$ & -- & 14 & 8 & 0 \\
\hline Fruit length $(\mathrm{cm})$ & $\begin{array}{c}\text { CA } 6 \text { x CA } 23(54.83), \\
\text { CA } 5 \text { x CA } 23(50.84), \\
\text { CA } 23 \text { x CA } 32 \\
(30.70)\end{array}$ & $\begin{array}{c}\text { CA } 6 \text { x CA } 23 \\
(22.31), \text { CA } 5 \times \text { CA } \\
23(18.28)\end{array}$ & $\begin{array}{c}\text { CA } 3 \text { x CA } 32 \\
(70.40), \text { CA } 8 \text { x CA } \\
32(64.74), \text { CA } 3 \text { x } \\
\text { CA } 5(60.19)\end{array}$ & 5 & 2 & 15 \\
\hline Fruit girth $(\mathrm{cm})$ & -- & -- & $\begin{array}{c}\text { CA } 3 \text { x CA } 23 \\
(108.71), \text { CA } 23 \text { x } \\
\text { CA } 32(107.84), \text { CA } \\
8 \text { x CA } 23(92.16)\end{array}$ & 0 & 0 & 15 \\
\hline Fruit weight $(\mathrm{g})$ & $\begin{array}{c}\text { CA } 32 \text { x CA } 23 \\
(29.53), \text { CA } 5 \text { x CA } 23 \\
(21.57), \text { CA } 6 \text { x CA } 23 \\
(19.69)\end{array}$ & $\begin{array}{c}\text { CA } 23 \times \text { xA } 32 \\
(28.75)\end{array}$ & $\begin{array}{c}\text { CA } 32 \text { x CA } 23 \\
(309.36), \text { CA } 5 \times \\
\text { CA } 23(230.06), \text { CA } \\
3 \text { x CA } 23(227.13)\end{array}$ & 3 & 1 & 15 \\
\hline Seeds per fruit & $\begin{array}{l}\text { CA } 3 \times \text { xA } 32(43.04), \\
\text { CA } 8 \text { x CA } 32(30.00)\end{array}$ & $\begin{array}{c}\text { CA } 3 \times \text { CA } 32 \\
(43.04)\end{array}$ & $\begin{array}{c}\text { CA } 3 \text { x CA } 32 \\
(111.48), \text { CA } 5 \text { x } \\
\text { CA } 23(88.04), \text { CA } \\
6 \text { x CA } 32(85.17)\end{array}$ & 2 & 1 & 15 \\
\hline $\begin{array}{l}\text { Green fruit yield per } \\
\text { plant }(\mathrm{g})\end{array}$ & $\begin{array}{c}\text { CA } 6 \text { x CA } 23 \\
(162.68), \text { CA } 23 \text { x CA } \\
32(132.62), \text { CA } 5 \text { x } \\
\text { CA } 23(116.39)\end{array}$ & $\begin{array}{c}\text { CA } 6 \text { x CA } 23 \\
(123.13), \text { CA } 23 \text { x } \\
\text { CA } 32(77.66), \text { CA } \\
5 \text { x CA } 23(77.62) \\
\end{array}$ & $\begin{array}{c}\text { CA } 23 \text { x CA } 32 \\
(57.90), \text { CA } 6 \text { x CA } \\
23(49.67), \text { CA } 8 \text { x } \\
\text { CA } 32(38.21)\end{array}$ & 15 & 14 & 10 \\
\hline Yield per plot (kg) & $\begin{array}{l}\text { CA } 6 \text { x CA } 23 \\
(227.18), \text { CA } 5 \text { x CA } \\
23(186.98), \text { CA } 23 \text { x } \\
\text { CA } 32(135.45)\end{array}$ & $\begin{array}{l}\text { CA } 6 \text { x CA } 23 \\
(174.48), \text { CA } 5 \text { x } \\
\text { CA } 23(129.72), \text { CA } \\
8 \text { x CA } 23(113.53) \\
\end{array}$ & $\begin{array}{l}\text { CA } 23 \text { x CA } 32 \\
(65.53), \text { CA } 6 \text { x CA } \\
23(54.51), \text { CA } 8 \times \\
\text { CA } 32(51.94)\end{array}$ & 14 & 13 & 10 \\
\hline
\end{tabular}

\section{Fruit weight (g)}

The fruit weight of hybrids varied from 6.34 to $14.43 \mathrm{~g}$ whereas that of parents from 6.76 to $11.21 \mathrm{~g}$ (Table 2). The magnitudes of heterosis for fruit weight were ranged from 42.30 to $28.75 \%$ and 78.87 to $309.36 \%$ over better parent and standard check, respectively. 
Only one cross were found with positive significant heterosis for fruit weight over better parent while fifteen crosses were found with significant positive heterosis over standard check. The top ranking hybrids for fruit weight over standard check were CA 32 x CA 23 (309.36\%), CA 5 x CA 23 (230.06\%) and CA 3 x CA 23 (227.13\%). Significant positive heterosis in respect of yield contributing characters like number of fruits per plant, fruit length, fruit girth and fruit weight was also reported by Anandanayaki and Natarajan (2000), Chaudhary et al., (2013) and Patel et al., (2014).

\section{Seeds per fruit}

Number of seeds per fruit should be less to make it more acceptable to the consumer. The number of seeds per fruit produced by the parental lines and F1hybrids varied from 83.66 to 120.00 and 99.66 to 147.33 , respectively (Table 2).The maximum useful heterosis for seeds per fruit was exhibited by the cross combination $\mathrm{CA} 3 \mathrm{x}$ CA 32 (43.04\%) and CA 3 x CA 32 (111.48\%) over better parent and standard check. Tembhurne and Rao (2012) also reported significant and positive heterobeltiosis and standard heterosis for seeds per fruit.

\section{Green fruit yield per plant (g)}

The green fruit yield per plant of parents and F1hybrids varied from 311.20 to $590.02 \mathrm{~g}$ and 177.66 to $1048.21 \mathrm{~g}$, respectively (Table 2). Among the parents, the maximum green fruit yield per plant was observed in CA 32 (590.02 g) fallowed by CA 3 (574.26 g) and CA 8 (520.07 g). The magnitudes of heterosis for green fruit yield were ranged from 14.90 to $162.68 \%,-69.06$ to $123.13 \%$ and -73.24 to $57.90 \%$ over mid parent, better parent and standard check, respectively (Table 3). Fifteen, fourteen and ten crosses were found with positive significant heterosis for green fruit yield per plant in $\mathrm{F}_{1}$ generation over mid parent, better parent and standard check. The maximum magnitudes of heterosis for green fruit yield per plant over better parent was noticed CA 6 x CA 23 (123.13\%) followed by CA 23 x CA $32(77.66 \%)$ and CA 5 x CA 23 (77.62\%). The top three ranking hybrids for green fruit yield per plant over standard check were CA 23 x CA 32 (57.90\%), CA 6 x CA $23(49.67 \%)$ and CA $8 \times$ CA $32(38.21 \%)$. Similar findings were also reported by Gandhi et al., (2000) and Patel et al., (2014) for both heterobeltiosis and standard heterosis. Tembhurne and Rao (2012) also reported significant and positive standard heterosis for green fruit yield.

\section{Yield per plot (kg)}

High total fruit yield per plant is one of the most important breeding objectives in any crop improvement programme. The yield per plot of parents and F1hybrids varied from 6.07 to $16.30 \mathrm{~kg}$ and 3.04 to $26.34 \mathrm{~kg}$, respectively (Table 2). The magnitudes of heterosis for yield per plot were ranged from 70.08 to $227.18 \%,-78.68$ to $174.48 \%$ and 80.86 to $65.53 \%$ over mid parent, better parent and standard check, respectively. Out of 15 hybrids, fourteen and thirteen hybrids were shown with positive significant heterosis for yield per plot in $F_{1}$ generation over mid parent and better parent and ten crosses over standard check. The three top ranking hybrids for yield per plot were CA 6 x CA 23 (174.48\%), CA 5 x CA 23 (129.72\%) and CA $8 \times$ CA 23 (113.53\%) over better parent and CA 23 x CA $32(65.53 \%)$, CA 6 x CA 23 $(54.51 \%)$ and CA $8 \times$ CA $32(51.94 \%)$ over standard check.

Evaluation of hybrids based on combination of per se and heterosis parameters would be more meaningful than on individual parameters. In the present study based on per 
se performance and heterosis, the hybrids $\mathrm{CA}$ $23 \times$ CA 32, CA $8 \times$ CA 32, CA 8 x CA 23, CA 6 x CA 32, CA 6 x CA 23, CA 6 x CA 8 CA $5 \times$ CA 32 and CA $5 \times$ CA 23 were found superior in respect of seven characters viz., days to first flowering, fruit length, fruit girth, fruit weight, seeds per fruit, green fruit yield per plant and yield per plot. The high heterotic response observed in these hybrids was further supported by the predominant role of non-additive component in the inheritance of the characters. These cross combinations could be exploited in heterosis breeding programme.

\section{References}

Anandanayaki, D., and Natarajan, S. 2000. Studies on heterosis for growth, flowering, fruit characters and yield in chilli (Capsicum annuum L.). South Indian Hort., 48: 53-55.

Chaudhary, A., Kumar, R., and Solankey, S.S. 2013. Estimation of heterosis for yield and quality components in chilli (Capsicum annuum L.). Afr. $J$. Biotechnol., 12: 6605-6610.

Dhall, R.K. 2008. Breeding for quality traits in chilli: A Review. J. Res. Punjab Agric. Univ., 45: 156-160.

Gandhi, S.D., Navale, P.A. and Venkatakrishna, K. 2000. Heterosis in chilli. $J$. Maharashtra Agric. Univ., 25: 71-73.

Hayes, H.K., Immer, I.R. and Smith, D.C. 1955. Methods of Plant Breeding, McGraw Hill Company, Inc., New York, 535p.Patel, A.L., Kathiria, K.B and Patel, B.R. 2014.
Heterosis in mild pungent chilli (Capsicum annuum L.). J. Spices Aromat Crops, 23: 178-185.

Prasath, D. and Ponnuswami, V. 2008. Heterosis and combining ability for morphological, yield and quality characters in paprika type chilli hybrids. Indian J. Hort., 65: 441-445.

Sadasivam, S. and Manickam, A. 1992. Biochemical Methods for Agricultural Sciences, Wiley Eastern Limited, Madras.

Shankarnag, B., Madalageri, M.B. and Mulge, R. 2006. Manifestation of Heterosis for earliness, growth and early green fruit yield in chilli. Indian J. Hort., 63: 410414.

Sharma, V.K., Punetha, S. and Sharma, B.B. 2013. Heterosis studies for earliness, fruit yield and yield attributing traits in bell pepper. Afr. J. Agric. Res., 8: 4088-4098.

Srivastava, H.K. 2000. Nuclear control and mitochondrial transcript processing with relevance to cytoplasmic male sterility in higher plants. Curr. Sci., 79: 176-186.

Tembhurne, B.V. and Rao, S.K. 2012. Heterosis and combining ability in CMS based hybrid chilli (Capsicum annuum L.). $J$. Agril. Sci., 4: 89-96.

Turner, J.H. 1953. A study of heterosis in upland cotton yield of hybrids compared with varieties combining ability and inbreeding effects. Agron. J., 45: 464470.

Woodbury, E.J. 1997. Extractable colour of capsicum and oleoresin paprika. J.A.O.A.C., 60: 1-4.

\section{How to cite this article:}

Mopidevi M. Nagaraju, I. Sreelathakumary, V.A. Celine, C.R. Sudharmai Devi and Manju, P. 2017. Heterosis Studies for Growth, Earliness, Fruit Yield and Yield Components in Chilli (Capsicum annuum L.). Int.J.Curr.Microbiol.App.Sci. 6(6): 1330-1336. doi: https://doi.org/10.20546/ijcmas.2017.606.156 